\title{
C-Fiber Assays in the Cornea vs. Skin
}

\author{
Eric A. Moulton ${ }^{1,2, *(1)}$ and David Borsook ${ }^{1}$
}

1 Center for Pain and the Brain, Department of Anesthesiology, Critical Care and Pain Medicine, Boston Children's Hospital, Harvard Medical School, 1 Autumn St, Boston, MA 02115, USA; david.borsook@childrens.harvard.edu

2 Department of Ophthalmology, Boston Children's Hospital, Harvard Medical School, 300 Longwood Ave, Boston, MA 02115, USA

* Correspondence: eric.moulton@childrens.harvard.edu; Tel.: +1-617-919-6827; Fax: +1-781-216-1983

Received: 27 September 2019; Accepted: 8 November 2019; Published: 12 November 2019

check for updates

\begin{abstract}
C-fibers are unmyelinated nerve fibers that transmit high threshold mechanical, thermal, and chemical signals that are associated with pain sensations. This review examines current literature on measuring altered peripheral nerve morphology and discusses the most relevant aspects of corneal microscopy, especially whether corneal imaging presents significant method advantages over skin biopsy. Given its relative merits, corneal confocal microscopy would seem to be a more practical and patient-centric approach than utilizing skin biopsies.
\end{abstract}

Keywords: in vivo corneal confocal microscopy; corneal nerves; neuropathic pain; innervation; small fiber neuropathy; subbasal nerve plexus; nociceptors; intraepidermal skin biopsy

\section{Introduction}

The morphological properties of small sensory nerve fibers provide important markers of overall health of the peripheral nervous system. For example, a diagnosis of small fiber neuropathy (SFN) requires evaluating a skin biopsy for small fiber afferent health. Though invasive and presenting a risk of bleeding and infection, skin biopsy remains the clinical gold standard to assess the health of these afferents. With the advent of laser scanning in vivo confocal microscopy performed in the human cornea, small-fiber afferents can now be imaged noninvasively and at high spatial resolution. This paper will focus on C-fibers and briefly summarize the literature regarding anatomy of corneal innervation, present the way corneal afferent imaging may be used as a tool in the study of sensation and pain, and discuss potential benefits and utility of corneal microscopy relative to traditional skin biopsy.

The cornea is the most densely innervated structure in mammals and has been reviewed in detail elsewhere [1]. It provides a number of unique features for clinical examination because it can be scanned in awake human subjects, has a well-defined anatomy in health, and can exhibit changes in both neural integrity and inflammatory cells in patients. Afferents within the cornea consist of C- and A-delta fibers (70\% vs. 30\% by number, in the mouse) [2], including polymodal nociceptors $(70 \%)$, mechano-nociceptors $(20 \%)$, and cold thermoreceptors $(10 \%)$. Derived from the long ciliary nerves, which extend from the nasociliary branch of the ophthalmic division of the trigeminal nerve (Cranial Nerve V), these sensory nerve fibers enter the globe medial and lateral to the optic nerve, course through in the suprachoroidal space, and branch to form nerve bundles that encircle the corneoscleral limbus and make up the limbal plexus. From the plexus, nerve trunks enter the corneal stroma radially and then ascend to innervate the corneal epithelium as free nerve endings through the subbasal nerve plexus, which primarily consists of C-fibers. As shown in the periphery [3], silent nociceptors are present and activated when the milieu is inflamed [4]. Unlike somatic nerve innervation, the cornea lacks A-beta fibers, and fibers involved in autonomic function are sparsely 
present [5]. Changes in corneal nerve function and structure through direct damage, metabolic changes, or systemic inflammatory processes may contribute to changes in corneal morphology.

In chronic pain conditions, nerve morphology alterations in the skin and cornea have been correlated with disease condition in both the peripheral and central nervous system [6-8]. However, these skin biopsy findings are not universal for all neuropathic pain conditions $[9,10]$. While skin biopsies have been sensitive for many small fiber or mixed neuropathies, the sensitivity and specificity of corneal nerve evaluation using corneal confocal microscopy (CCM) is less well defined. Furthermore, differences or similarities between these methods have not been stringently evaluated. While differences in fiber density across different body sites may contribute to variable sensitivity to stimuli, the overriding questions are: If small fibers are affected by a disease, is there also widespread fiber change?; can disease conditions result in alterations in small-fiber density in both the cornea and skin?

Quantitative approaches to measuring altered nerve morphology may contribute to understanding a disease state or its responsiveness to treatment. Some 7000+ PubMed citations are listed for the search term "skin biopsy and pain" and some 22 for "corneal nerve measures and pain". While the overall sense is that both are sensitive to alterations in innervation, the issue is whether corneal imaging presents significant advantages over skin biopsy. Skin biopsies can evaluate patients with symptoms of numbness, tingling, or pain. Corneal imaging can evaluate patients with symptoms of itching, pain, discomfort, photophobia, and intolerance to cold. Both can be used to assess the health of small fibers in systemic disorders [11,12].

\section{C-Fibers-Morphological Dynamics}

In the context of baseline measures and responses to treatments, C-fiber health must be considered. C-fiber stimulation is associated with evoking a number of different sensations, including pain, warmth, itching, and sensual touch. Furthermore, a subclass of C-fibers demonstrate hyper-responsivity in diabetic neuropathy [13]. Sensitized C-fibers are more responsive to suprathreshold mechanical stimuli vs. uninjured control fibers [14]. With respect to functional properties associated with C-fiber nerve fiber density, physical regeneration and sensitivity of regenerated fibers are important to consider. Peripheral afferents can regenerate up to approximately $3.2 \mathrm{~mm}$ per day after unconditioned nerve crush injuries in a rodent model [15], and regeneration rates in disease states may contribute to opportunities for understanding drug efficacy in disease modification. Insight into this process in humans has been evaluated using a capsaicin-induced denervation model, which resulted in nearly complete degeneration of epidermal and subepidermal nerves [16]. In healthy volunteers, this intradermal capsaicin denervation model demonstrated reinnervation and recovery of limited sensation just three weeks post-injection. Compared with healthy subjects, the rate of nerve fiber density regeneration is significantly reduced in patients with diabetes [17], as well as in Human Immunodeficiency Virus (HIV) infection [18]. Importantly, regeneration may be affected by a number of factors, including mitochondrial dynamics within the nerve cell bodies [19], as well as presence of cytokines/macrophages [20]. Thus, measures of nerve fiber regeneration in disease states, or in response to a potentially modifying treatment, must account for issues related to the structural state of C-fibers, their rate of regeneration, and their subsequent altered functional sensitivity.

\section{Methods for Quantitation of C-Fiber Changes}

\subsection{Intraepidermal Skin Biopsy (IESB)}

Skin biopsy can be used for measurements of intraepidermal nerve fiber density (IENFD) of C-fibers (unmyelinated nerves) [21]. Using protein gene product (PGP) antibody labeling, which binds to unmyelinated nerve fibers, the density of these nociceptive fibers can be evaluated. Intraepidermal skin biopsy (IESB) is widely available and provides an objective assay of changes in distal nerve fiber integrity: 
i. Data Collection: IESB is a relatively simple in approach, can be performed in clinical outpatient offices, and has commercial kits available for the procedure. Punch biopsies of the skin are taken from the region of interest, and the linear density of IENFD is quantified. The procedure, as defined previously, includes examining "at least three $50-\mu \mathrm{m}$-thick sections per biopsy, fixed in $2 \%$ paraformaldehyde lysine periodate or Zamboni's solution, by bright-field immunohistochemistry or immunofluorescence, with anti-PGP 9.5 antibodies" [22]. The antibody PGP9.5 (protein gene product 9.5) is a neuron-specific protein that allows labeling of neurons and nerve fibers at all levels of the nervous system. Currently, a standard battery of antibodies to differentiate nerve fibers, such as $C$ vs. A-delta vs. A-beta, has not yet been established. Such a test would be helpful for differential diagnoses of pathologies that differentially affect these nerve fibers, such as SFN.

ii. Data Analysis: Analysis involves quantification of fibers that intersect the dermal-epidermal basement membrane. A number of laboratories can now provide quantification of the skin biopsy. Details are provided elsewhere [21].

iii. Sensitivity and Specificity: IESB is considered to be reliable and reproducible [23]. Although the state or stage of the disease is difficult to define, multiple skin biopsies may be taken, allowing for longitudinal measurement of relative changes in a particular patient, as well as evaluation of clinical correlations, including disease etiology. Reduced IENFD is both sensitive and specific for well-defined clinical syndromes, but clinical phenotyping can be nonspecific. For example, in a retrospective report, IENFD abnormalities were detected in $88 \%$ of patients with symptoms suggestive of SFN, which was significantly better compared with a clinical exam or quantitative sensory testing (QST) [24]. In addition, IENFD was abnormal in approximately $80 \%$ of clinically defined mixed large- and small-fiber neuropathies, with no changes observed in large-fiber neuropathy.

iv. Disease Evaluation: Skin biopsy for small-fiber abnormalities has been shown across well-described conditions that have SFN (e.g., HIV, diabetes, chemotherapy-induced neuropathy), mixed peripheral neuropathies, and also in conditions having less defined pathophysiologies (e.g., Parkinson's or fibromyalgia) and autonomic neuropathies. The European Federation of Neurological Societies has provided guidelines for the use of skin biopsy in the diagnosis of peripheral neuropathies [22]. Diagnostic specificity and sensitivity using IESB is high. Normative data has been provided in healthy controls and neuropathic patients [25]. These authors reported the number of intraepidermal fibers in normal controls to be $21.1 \pm 10.4$ per $\mathrm{mm}$ (mean $\pm \mathrm{SD}$ ) in the thigh (fifth percentile, 5.2 per $\mathrm{mm}$ ) and $13.8 \pm 6.7$ per $\mathrm{mm}$ at the distal part of the leg (fifth percentile, 3.8 per $\mathrm{mm}$ ). Using a cutoff taken from the fifth percentile of healthy data, they concluded that the approach had "a positive predictive value of $75 \%$, a negative predictive value of $90 \%$, and a diagnostic efficiency of $88 \% "$.

v. Data interpretation: IESB has been useful in evaluating small-fiber neuropathies across multiple small-fiber neuropathies and mixed-fiber neuropathies (see Table 1). IEDNF is reduced in patients with small-fiber neuropathy and mixed-fiber neuropathy, but not in large-fiber neuropathies. Because $\mathrm{C}$-fibers function for thermal and pain transduction, thermal testing for noxious heat can be a useful or confirmatory adjunct [16]. 
Table 1. Reports of cornea or skin-based nerve metrics on corneal confocal microscopy (CCM) or intraepidermal skin biopsy (IESB) measures in different conditions/disease states in humans.

\begin{tabular}{|c|c|c|}
\hline \multirow[t]{2}{*}{ Condition/Disease } & \multicolumn{2}{|l|}{ Method } \\
\hline & CCM & IESB \\
\hline \multicolumn{3}{|l|}{ Physiological States } \\
\hline Healthy & $\begin{array}{l}\text { [26] } 64 \text { subjects-CNFL is not associated with age and contact lens wear } \\
\text { [27] } 343 \text { subjects-height, weight, and body mass index do no influence } 5 \text { th } \\
\text { percentile normative values for any corneal nerve parameter }\end{array}$ & $\begin{array}{l}\text { [28] } 192 \text { subjects-IENFD is associated with } \\
\text { anatomic site, race, and age, and not gender }\end{array}$ \\
\hline Aging & $\begin{array}{l}\text { [29] } 85 \text { subjects - CNFD decreases with age } \\
\text { [27] } 343 \text { subjects—-decreased CNFD and CNFL with age; corneal nerve fiber } \\
\text { tortuosity increases with age }\end{array}$ & $\begin{array}{l}\text { [30] } 10 \text { subjects-little age-related change in IENFD } \\
\text { [31] } 528 \text { subjects-IENFD is associated with age and } \\
\text { gender }\end{array}$ \\
\hline Capsaicin Application & - & $\begin{array}{l}\text { [32] } 10 \text { subjects-IENFD decreased } 3 \text { days following } \\
\text { capsaicin }\end{array}$ \\
\hline Local Anesthetic Application & - & $\begin{array}{c}\text { [33] } 20 \text { subjects-decreased IENFD after } 42 \text { days of } \\
\text { lidocaine patch treatment }\end{array}$ \\
\hline \multicolumn{3}{|l|}{ Eye-Related Conditions } \\
\hline Dry Eye & $\begin{array}{l}\text { [34] } 24 \text { non-Sjogren's dry eye; } 44 \text { Sjogren's dry eye; } 24 \text { controls- decreased CNFD, } \\
\text { increased tortuosity, and increased DC in both dry eye groups }\end{array}$ & - \\
\hline $\begin{array}{l}\text { Laser-assisted in situ keratomileusis } \\
\text { (LASIK) }\end{array}$ & {$[35] 3$ patients—reduced CNFD } & - \\
\hline Herpes Zoster Ophthalmicus (HZO) & $\begin{array}{l}\text { [36] } 24 \mathrm{HZO} \text { affected eyes; } 24 \text { contralateral unaffected eyes; } 24 \\
\text { controls-decreased CNFL, CNFD, CNFB, and increased DC density }\end{array}$ & - \\
\hline \multicolumn{3}{|l|}{ Pain-Related Conditions } \\
\hline Chronic Migraine & $\begin{array}{l}\text { [38] } 24 \text { migraineurs w/photophobia; } 24 \text { migraineurs w/o photophobia; } 24 \\
\text { controls—decreased CNFL, CNFA, CTBD, CNBD }\end{array}$ & - \\
\hline Fibromyalgia & $\begin{array}{l}\text { [39] } 34 \text { patients; } 42 \text { controls - decreased total nerve density, long nerve fibers, } \\
\text { number of nerves } \\
\text { [40] } 17 \text { patients; controls—decreased CNFD }\end{array}$ & [8] 46 patients; 34 controls-reduced IENFD \\
\hline Chemotherapy-Induced Neuropathy & $\begin{array}{l}\text { [41] } 21 \text { patients; } 21 \text { controls-decreased CNFD, CNBD, and CNFL; increased } \\
\text { CNFL after 3rd cycle of chemotherapy }\end{array}$ & $\begin{array}{l}\text { [10] } 13 \text { patients; } 47 \text { controls-no significant decrease } \\
\text { in IENFD }\end{array}$ \\
\hline
\end{tabular}


Table 1. Cont.

$\begin{array}{r}\text { Condition/Disease } \\ \hline \text { Herpes Zoster Ophthalmicus }\end{array}$

Small-Fiber Neuropathy (SFN)

\section{Pruritus}

Trigeminal Neuralgia (post-compression

surgery of trigeminal ganglion)

Immunological Disease

Sjogren's Disease

Behcet's Disease

Sarcoidosis

Systemic Lupus Erythematosus

General Neuropathies

Diabetic Neuropathy

\section{Metabolic Syndrome}

Autonomic Neuropathy

Vitamin D Deficiency

Amyloid Polyneuropathy

Chronic Inflammatory Demyelinating Polyneuropathy (may include other $\mathrm{dx}$ )

Peripheral Autoimmune Neuropathy
[36] 24 affected eyes; 24 unaffected contralateral eyes: 24 controls-increased DC in both eyes

[42] 14 patients; 14 controls—decreased CNFD and total number of nerves; increased nerve tortuosity.

[40] 17 patients; 17 patients—-decreased CNFD

$$
\text { - }
$$

[44] 21 affected eyes; 21 unaffected contralateral eyes—no change in CNFD

[34] 24 non-Sjogren's dry eye; 44 Sjogren's dry eye: 24 controls—decreased CNFD, increased nerve tortuosity, and DC with both dry eye groups

[45] 30 patients; 12 controls-increased corneal nerve entropy

[47] 49 patients; 30 controls-decreased CNFD and CNFL; increased DC density

[48] 58 patients-decreased CNFL, CNFD, or CNBD in $45 \%$ of patients

$$
\text { [50] } 27 \text { patients; } 27 \text { controls }
$$$$
\text { ncreased central DC density }
$$

[52] 30 Type 1 diabetes without neuropathy; 31 Type 1 diabetes with neuropathy; 27 controls-decreased CNFD, CNBD, and CNFL in patients with neuropathy vs. without and controls

\section{[56] 3 patients; 3 controls-decreased CNFD}

[57] case report-increased DC

[58] 15 patients; 15 controls—decreased CNFL

[60] 16 patients; 15 controls—-decreased CNFD and CNFL; increased nerve tortuosity

[61] case report-increased tortuosity of stromal nerves; no change in subbasal
[7] 25 idiopathic SFN; 13 impaired glucose tolerance (IGT)-associated SFN; 14 diabetes mellitus

(DM)-associated SFN—-decreased IENFD with IGT and DM vs. idiopathic SFN.

[43] review paper-decreased IENFD

[46] 61 patients; 106 controls—decreased IENFD

[48] Decreased IENFD in $28 \%$ of patients [49] 72 patients; 188 controls-decreased IENFD [46] 60 patients; 106 controls-decreased IENFD [51] 60 patients-decreased IENFD

[53] 32 recent-onset Type 2 diabetes; 34 diabetic sensorimotor polyneuropathy (DSPN) + pain; 32 DSPN-pain; 50 controls

[54] 35 Type 2 diabetes; 32 metabolic syndromes; 36 metabolic syndromes for longitudinal testing

[54] 35 Type 2 diabetes; 32 metabolic syndromes: 36 metabolic syndromes for longitudinal

testing-decreased IENFD in both patient groups

[55] 38 patients-decreased IENFD

[21] review article—-decreased IENFD

[59] 70 transthyretin (TTR)-mutant; 66

TTR-A975-decreased IENF density

[46] 60 Systemic Lupus Erythematosus; 61 Sjogrens; 52 Rheumatoid Arthritis; 106 controls—-decreased IENFD 
Table 1. Cont.

\begin{tabular}{c} 
Condition/Disease \\
\hline Human Immunodeficiency Virus
\end{tabular}

Neuropathy

Arterial Ischemic Disease

Central Nervous System (CNS)

Disorders

Charcot Marie Tooth

Parkinson's Disease

Stroke/Central Post-Stroke Pain

Fabry Disease

Amyotrophic Lateral Sclerosis (ALS)

Multiple Sclerosis

Wilsons Disease

Friedrich's Ataxia

Ehlers-Danlos Syndrome

Drug-Induced Conditions

Pregabalin

Corticosteroids

Cyclosporine

Cibenetide

Crack Cocaine Use

Vitamin B Deficiency

Method

\section{CCM}

IESB

[62] 20 patients; 20 controls—-decreased CNFD, CNBD, and CNFL; increased tortuosity

[66] 12 patients; 12 controls-decreased CNFD, CNBD, CNFL, and tortuosity [68] 26 patients; 26 controls-decreased CNFD; increased CNBD and CNFL

[70] 146 patients; 18 controls-decreased CNFD, CNBD, and CNFL

[71] 10 heterozygous females w/Fabrys w/o enzyme replacement therapy (ERT); 6 heterozygous females w/Fabrys w/ERT; 6 heterozygous males w/Fabrys w/ERT; 14 controls-decreased CNFD and CNBD

[74] 26 patients; 26 controls-decreased CNFD

[75] 24 patients; 24 controls-decreased corneal nerve fiber density, number of branchings, number of beadings, and tortuosity.

$$
\text { [76] } 23 \text { patients; } 14 \text { controls-decreased CNFD and CNFL }
$$

[78] 50 patients; 50 controls—-thinner stroma, lower keratocyte densities, increased applanation-related stromal folds, increased endothelial hyperreflective dots.

\section{[81] 50 subjects—decreased DC density}

[82] 40 subjects-decreased CNFD, reflectivity, tortuosity, and hyperreflective keratocytes; increased cell density of intermediate epithelium cells [83] 64 subjects-increased CNFA

[84] case report-decreased CNFD and CNFL; increased tortuosity -
[63] 62 patients

[64] 101 distal leg, 99 proximal thighs-decreased ENFD

[65] 20 symptomatic peripheral arterial disease; 20 critical leg ischemia; 12 controls-decreased IENFD

[67] 80 patients-decreased IENFD

[69] 28 patients; 23 controls-decreased IENFD

[68] 24 patients; 10 controls-decreased IENFD [6] 4 patients-decreased IENFD

[72] 120 patients—decreased IENFD

[73] 8 ALS; 5 facial onset sensory and motor neuronopathy-decreased IENFD

[77] 17 patients—decreased IENFD

[79] 24 patients—decreased IENFD

[80] 26 subjects—IENFD lower in non-responders

[85] 10 patients; 10 controls-decreased IENFD

Corneal nerve branch density (CNBD), corneal nerve fiber area (CNFA), corneal nerve fiber branches (CNFB), corneal nerve fiber density (CNFD), corneal nerve fiber length (CNFL), corneal total branch density (CTBD), dendritic cells (DC), intraepidermal nerve fiber density (IENFD). 


\subsubsection{State Evaluation}

(1) Static evaluation: Single nerve biopsies may be useful in diagnosis, but evaluation across gender and race/ethnicity has not been fully researched. For example, skin biopsy values in a Chinese population for diagnosing SFN have shown low sensitivity [86].

(2) Dynamic evaluation: Despite the capacity for repeated measurements, few longitudinal studies have evaluated the utility of IESB. Some studies have evaluated the effects of age on epidermal sensory innervation [87]. Their findings noted an age-associated decrease in the facial biopsies, but not in biopsies derived from the abdomen. Evaluation of SFN in three clinical groups (idiopathic, impaired glucose tolerance, and diabetes) showed similar decreases over three time points at three sites (proximal thigh, distal thigh, and distal leg), noting similar rates of decrease in the different clinical categories over time [7]. Thus, axon loss may not be length-dependent over time, and the process inducing these changes may be local rather than at the level of the cell bodies [88]. However, IESB measures of SFN have been associated with central nervous system changes in patients following the development of central post-stroke pain [6]. It was unclear whether there was a true correlation/causality of the disease or whether the age of the patients in central post-stroke pain played a role (all were $>50$ years old), although none of the patients had a diagnosis consistent with coexistent SFN and the extent of reduced fiber density observed in the calf $(<3.4$ fibers per $\mathrm{mm}$ ) was well below normal, even when accounting for age. Of note, a study in Parkinson's patients detected no changes in IEDNF, although decreases in corneal nerve-fiber density and length were detected using CCM [89].

\subsubsection{Autonomic Nerve Assessment [21]}

A complex relationship exists between epidermal fibers and autonomic function. Changes in IENFD have been observed in conditions, such as amyotrophic lateral sclerosis (ALS)—not previously thought to have a pathophysiology affecting epidermal nerves [90]. In ALS, one mechanism of alteration in nerve fibers may relate to the deposition of transactive response DNA-binding protein (TDP)-43/pTDP-43 [91]

\subsection{Corneal Confocal Microscopy (CCM)}

CCM is a method for evaluating alterations in corneal fibers in vivo using confocal microscopy. Unlike skin biopsy, the approach is noninvasive, easily repeated for the same region, and offers an alternative method to detect changes in nerve morphology for various pain conditions, both peripheral and central (see Table 1). Though imperfect (see limitations below), measures of altered corneal nerve morphology may be considered a marker for nerve damage [92]. CCM provides more information on nerve morphometry than can be obtained by skin biopsies, including fiber length and fiber branching. The association between abnormal corneal nerve morphology and generalized pain conditions (e.g., fibromyalgia) is not well understood. The ability to differentiate $C$ vs. A-delta fibers in the cornea is limited as myelination, a defining morphological feature of A-delta fibers, does not extend significantly into the cornea.

i. Data collection: CCM is an outpatient procedure that requires specialized equipment, such as a Heidelberg Retinal Tomograph II/III with a Rostock Corneal Module. Because the microscope lens makes brief contact with the cornea, an anesthetizing eye drop of $0.5 \%$ proparacaine is applied prior to image acquisition. The procedure usually takes less than $15 \mathrm{~min}$. Data is electronically captured and stored for analysis. Approach and data collection have been described in detail elsewhere [27].

ii. Data analysis: Analysis may be performed manually or, more recently, using a fully automated approach [93-95]. Using these approaches, data may be collected in the categories of: Corneal nerve fiber density (CNFD), branch density (CNBD), and nerve fiber length (CNFL) and width (CNFW). For example, CNFD is a measure of the major corneal nerves and is expressed in 
fibers per $\mathrm{mm}^{2}$; CNBD measures the density of nerve branches off the major corneal nerves using the number of branch points on main fibers per $\mathrm{mm}^{2}$; CNFL reflects the total length of the nerves in $\mathrm{mm}$ per $\mathrm{mm}^{2}$. Taken together, these measurements can be used for evaluating disease state (i.e., severity, progression, regression) and treatment effects for diseases affecting the C-fibers. Normative data is also available to facilitate comparisons [27].

iii. Sensitivity and Specificity: CCM is a sensitive method to evaluate corneal metrics in healthy and disease states. Methods for improving sensitivity and specificity include sampling an average of three representative standard images [96], as well as large-area mosaic imaging of the subbasal nerve plexus [97]. Automated vs. manual evaluation of corneal fiber metrics show consistency within and across evaluators [98]. Comparisons of CCM and IESB measures have shown an equivocal sensitivity and specificity in the detection of diabetic sensorimotor polyneuropathy [99] and sometimes higher sensitivity with CCM. In a comparative study in the detection of diabetic neuropathy, CNFD showed slightly higher diagnostic sensitivity than IESB ( 0.77 vs. 0.61$)$ and comparable specificity ( 0.79 vs. 0.80$)$ [52]. Another comparative study, this one in the detection of sarcoidosis, found that IESB was again less sensitive than CCM, with decreased IENFD found in $28 \%$ of patients, while CCM abnormalities were present in $45 \%$ of patients [48]. However, studies need to be performed to further understand the correlation between these two approaches, for their utility for diabetes and sarcoidosis, as well as other disease states.

iv. Disease Evaluation: CCM offers the opportunity to (a) define changes in small fibers in a disease ahead of clinical symptomatology; (b) potentially predict disease onset [100]; and (c) possibly define treatment efficacy in an objective manner [101,102]. Changes in corneal innervation may be evaluated for specific corneal pathology and for systemic disease. While changes in corneal innervation are not specific to pain, most pain conditions studied to date show altered CCM metrics (see Table 1). However, other diseases, such as multiple sclerosis or Parkinson's disease, also show changes. Since pain can be associated with these diseases, changes may represent the development of pre-pain conditions; for example, Parkinson's disease is associated with central and peripheral neuropathic or muscular pain.

v. Data Interpretation: Changes in nerve integrity may correlate with systemic disease, including pain, but may also be altered in other neurological conditions, such as multiple sclerosis [103], Parkinson's disease [68], Friedreich's ataxia [76], or chronic demyelinating polyneuropathy [104]. Importantly, changes may reflect systemic rather than local symptomatology, as has been shown with a prediction of the development of peripheral neuropathy in diabetic neuropathy [105]. Only a few studies have indicated that CCM can be utilized to evaluate a therapeutic response to treatment [101]. A few corneal indices, such as investigation of the inferior whorl, may also help define painful vs. non-painful states, although this observation needs to be studied further in pain vs. non-pain states [106].

(1) State evaluation: Similar to IESB, CCM measures across sex and race/ethnicity are still an active area of investigation. For example, a meta-analysis of normative values in a 343-healthy-subject cohort did not show sex differences in CCM measures [27].

(2) Dynamic evaluation: While repeated IEDNF measures are possible with skin biopsies adjacent to each other, CCM allows for multiple measures across time in the same sampling region. This allows for dynamic evaluation of afferent health in response to condition or therapy. 


\section{Skin Biopsy vs. Corneal Microscopy}

\subsection{Age Domain}

CCM may be conducted across ages, at least from 8 years or older. No injections of local anesthetic or "traumatic" injury are required. If standard precautions for infection prevention are not followed, there is a risk of ocular infection. While a theoretical risk exists with excessive light exposure, photochemical damage has been estimated to occur when continuous exposure exceeds $8 \mathrm{~h}$ with optical coherence tomography, the technological basis of CCM [107]. Skin biopsies can be performed at any age, though special considerations are necessary as it is a minor invasive procedure [108].

\subsection{Disease Domain}

Changes are observed in both skin and corneal measures in "systemic" diseases (Table 1, Table 2), such as Parkinson's disease. IENFD (including myelinated nerves innervating Meissner corpuscles) is reported as lower in Parkinson's disease patients vs. controls, with a greater impact on the body side with greater symptoms [109]. CCM has shown significant decreases in CNFD, CNBD, and CNFL in patients with dementia and even mild cognitive impairment [110]. These findings highlight the equal utility of each technique to potentially monitor systemic changes in the peripheral and central nervous system (Table 1).

Table 2. Relative advantages of CCM vs. IESB in evaluating C-fiber changes.

\begin{tabular}{|c|c|c|}
\hline Condition & $\mathrm{CCM}$ & IESB \\
\hline Age & Suitable for ages $>8$ years, noninvasive & $\begin{array}{l}\text { All ages, but invasive; in some } \\
\text { conditions, healing may be affected }\end{array}$ \\
\hline Disease State & Many pain and non-pain conditions & Many pain and non-pain conditions \\
\hline Temporal Measures & $\begin{array}{c}\text { Temporal Dynamics easily evaluated, } \\
\text { including short and long-term } \\
\text { evaluation }\end{array}$ & Temporal dynamics not easily evaluated \\
\hline $\begin{array}{l}\text { Measures of Degeneration or } \\
\text { Regeneration }\end{array}$ & Can evaluate the same region repeatedly & Can evaluate neighboring regions \\
\hline Correlative Measures & $\begin{array}{c}\text { Extraterritorial changes can be } \\
\text { evaluated }\end{array}$ & $\begin{array}{c}\text { Thermal pain using quantitative sensory } \\
\text { testing }\end{array}$ \\
\hline Quantitative Sensitivity & $\begin{array}{c}\text { Good repeated measures across } \\
\text { evaluators or automated measures }\end{array}$ & $\begin{array}{l}\text { Good across evaluators assuming } \\
\text { appropriate skin punch biopsy taken }\end{array}$ \\
\hline $\begin{array}{l}\text { Predictive Value for } \\
\text { Neuropathy }\end{array}$ & Good & Good \\
\hline Inflammatory Markers & $\begin{array}{c}\text { Good; inflammatory cells can be } \\
\text { visualized }\end{array}$ & Good; requires staining \\
\hline Adaptive Clinical Models & $\begin{array}{l}\text { Keratoplasty, to assess nerve fiber } \\
\text { damage and regeneration }\end{array}$ & $\begin{array}{l}\text { Capsaicin denervation, to assess nerve } \\
\text { fiber retraction and reversal }\end{array}$ \\
\hline
\end{tabular}

\subsection{Temporal Domain}

$\mathrm{CCM}$ can be evaluated longitudinally, measuring within the same area. To reduce variability due to sampling area selection, automated spatial registration of the cornea remains an area in active development. The amount of time required for some corneal measures to return to normal, including ongoing regeneration, may take years [111].

\subsection{Degeneration and Regeneration}

Degeneration in corneal nerve morphology is evidenced by multiple changes, including nerve tortuosity, nerve fiber orientation, and decreased nerve density. For local conditions, such as corneal nerve damage following laser-assisted in situ keratomileusis (LASIK) [111,112], CCM evaluation can provide an objective assay of recovery that may correlate with clinical symptoms. A number of studies have used CCM to evaluate corneal nerve regeneration [113]. IESB has also been used to study regeneration, as abnormalities in nerve regeneration rates have also been demonstrated in patients with HIV [18,63] and diabetes [17]. We are unaware of any study that has directly correlated corneal 
nerve regeneration with pain levels or pain reversal, and IESB measures do not correlate well with neuropathic pain with peripheral neuropathies [9]. Corneal nerve migration rate is a useful measure of regeneration; in healthy subjects it has been reported to be approximately $42 \mu \mathrm{m}$ per week with no sex or age differences [114]. Neurotrophic factors have been identified that promote nerve regeneration in animal models [115-117] as well as humans [118].

\subsection{Correlative Measures}

Other methods of evaluation of C-fiber loss or dysfunction in the skin include quantitative sensory testing (QST) [119] and laser doppler imaging flare [120]. For example, thermal sensory testing provides a behavioral response consistent with C-fiber loss and can readily evaluate skin regions across diseases [121]. In the case of the cornea, menthol produces uncomfortable sensations in patients with dry eye, a potentially neuropathic condition [122]. Although cold sensitivity is considered to be part of corneal fiber loss or changes (e.g., dry eye) and is also associated with neuropathic pain conditions $[123,124]$, corneal sensitivity tests, also known as corneal esthesiometry, include the Belmonte and Cochet-Bonnet aesthesiometers and the relatively crude corneal reflex test using a cotton swab. C-fiber structure in the cornea is not routinely evaluated across pain conditions at this time.

\subsection{Quantitation Domain}

Although IEDNF is considered a reproducible and reliable method [23], this is controversial [125]. Evaluation requires preparation via staining, and quantitation is not automated; it has been suggested that reproducibility is higher if three images acquired from different areas of the cornea are analyzed [23]. CCM provides essentially immediate results and can be quantitated in minutes. The current evaluative methods seem to be reproducible within and across observers and with manual vs. automated counting by at least two separate research groups $[98,126,127]$. For clinical diagnostic testing, manual evaluation of the needed number of sections is more tedious and less cost-effective than automated analysis. Cross-study reproducibility is key to evolving CCM to clinical utility and is an important area to establish with future studies.

\subsection{Predictive Domain}

Measures of changes in nerve fiber metrics can be more easily evaluated using the CCM approach, because both local and systemic effects can be evaluated. CCM changes have predicted changes in the future onset of neuropathy disease severity in diabetes type 1 [128] but are not well defined in other disease domains, nor in the context of pain. Specific measures, such as nerve fiber length, may be more sensitive in differentiating diabetics from healthy patients and thus may have some predictive value as a screening test $[100,105,129]$.

\subsection{Clinical Models of Nerve Changes}

Some clinical treatments provide ideal models with which to evaluate changes in fiber density and reinnervation. Examples include: (1) Nerve damage treatments, including post-LASIK-a procedure that severs corneal nerves [130,131]; (2) toxic treatments, such as chemotherapy [41], in which CCM has the potential to be more sensitive than IESB [10]; and (3) endocrine-related treatments in diabetic neuropathy. For direct trauma/surgery to the skin, IESB has not been used in humans but has been observed in entrapment neuropathy in rats, a model for chronic compression injury [132].

\subsection{Drug Evaluation}

Open access to the cornea is a good reason to utilize measures of nerve morphology as an index of drug efficacy and disease modification. Since changes in the cornea may predict disease onset (e.g., diabetic peripheral neuropathy), the opposite may also be true. Both systemic and local effects of drugs on corneal nerves can be evaluated, whether to assess therapeutic efficacy or as a pharmaceutical 
side effect. A robust approach to this-considering dosing and time for effect-has not yet been conducted. However, supportive data for such an approach is a compelling need.

\section{Conclusions}

Evaluation of nerve health provides insight into dynamic changes of the peripheral nervous system during disease states or treatment effects. The notion of a "peripheral-only" or "central-only" pathogenesis of pain seems to be progressively eroding as our understanding of the interaction between peripheral and central nervous system changes takes place in pain conditions. The cornea provides an ideal window into these processes. While more information is required to define corneal changes as true biomarkers, it would seem to be a more practical and patient-centric approach than utilizing skin biopsies.

Funding: This work was supported by the Mayday Fund (EM), the Anesthesia Distinguished Trailblazer Award (EM), and the Anesthesia Foundation at Boston Children's Hospital (EM).

Acknowledgments: Funding for this work was made possible by the Mayday Fund (EAM), the Anesthesia Research Distinguished Trailblazer Award (EAM), and discretionary funds from Department of Anesthesiology, Critical Care, and Pain Medicine at Boston Children's Hospital (EAM). We would also like to thank science writer, Jane Patrick, for assistance with proofreading and copy editing.

Conflicts of Interest: The authors declare no conflict of interest.

\section{References}

1. Shaheen, B.S.; Bakir, M.; Jain, S. Corneal nerves in health and disease. Surv. Ophthalmol. 2014, 59, $263-285$. [CrossRef] [PubMed]

2. Belmonte, C.; Acosta, M.C.; Gallar, J. Neural basis of sensation in intact and injured corneas. Exp. Eye Res. 2004, 78, 513-525. [CrossRef] [PubMed]

3. Prato, V.; Taberner, F.J.; Hockley, J.R.F.; Callejo, G.; Arcourt, A.; Tazir, B.; Hammer, L.; Schad, P.; Heppenstall, P.A.; Smith, E.S.; et al. Functional and Molecular Characterization of Mechanoinsensitive "Silent" Nociceptors. Cell Rep. 2017, 21, 3102-3115. [CrossRef] [PubMed]

4. González-González, O.; Bech, F.; Gallar, J.; Merayo-Lloves, J.; Belmonte, C. Functional Properties of Sensory Nerve Terminals of the Mouse Cornea. Investig. Ophthalmol. Vis. Sci. 2017, 58, 404-415. [CrossRef] [PubMed]

5. Müller, L.J.; Marfurt, C.F.; Kruse, F.; Tervo, T.M.T. Corneal nerves: Structure, contents and function. Exp. Eye Res. 2003, 76, 521-542. [CrossRef]

6. Cavalier, Y.; Albrecht, P.J.; Amory, C.; Bernardini, G.L.; Argoff, C.E. Presence of Decreased Intraepidermal Nerve Fiber Density Consistent with Small Fiber Neuropathy in Patients with Central Post-Stroke Pain. Pain Med. 2016, 17, 1569-1571. [CrossRef] [PubMed]

7. Khoshnoodi, M.A.; Truelove, S.; Burakgazi, A.; Hoke, A.; Mammen, A.L.; Polydefkis, M. Longitudinal Assessment of Small Fiber Neuropathy: Evidence of a Non-Length-Dependent Distal Axonopathy. JAMA Neurol. 2016, 73, 684-690. [CrossRef] [PubMed]

8. Kosmidis, M.L.; Koutsogeorgopoulou, L.; Alexopoulos, H.; Mamali, I.; Vlachoyiannopoulos, P.G.; Voulgarelis, M.; Moutsopoulos, H.M.; Tzioufas, A.G.; Dalakas, M.C. Reduction of Intraepidermal Nerve Fiber Density (IENFD) in the skin biopsies of patients with fibromyalgia: A controlled study. J. Neurol. Sci. 2014, 347, 143-147. [CrossRef] [PubMed]

9. Truini, A.; Biasiotta, A.; Di Stefano, G.; Leone, C.; La Cesa, S.; Galosi, E.; Piroso, S.; Pepe, A.; Giordano, C.; Cruccu, G. Does the epidermal nerve fibre density measured by skin biopsy in patients with peripheral neuropathies correlate with neuropathic pain? Pain 2014, 155, 828-832. [CrossRef] [PubMed]

10. Velasco, R.; Navarro, X.; Gil-Gil, M.; Herrando-Grabulosa, M.; Calls, A.; Bruna, J. Neuropathic Pain and Nerve Growth Factor in Chemotherapy-Induced Peripheral Neuropathy: Prospective Clinical-Pathological Study. J. Pain Symptom Manag. 2017, 54, 815-825. [CrossRef] [PubMed]

11. Sommer, C. Skin biopsy as a diagnostic tool. Curr. Opin. Neurol. 2008, 21, 563-568. [CrossRef] [PubMed]

12. Wang, E.F.; Misra, S.L.; Patel, D.V. In Vivo Confocal Microscopy of the Human Cornea in the Assessment of Peripheral Neuropathy and Systemic Diseases. BioMed Res. Int. 2015, 2015, 951081. [CrossRef] [PubMed] 
13. Chen, X.; Levine, J.D. Hyper-responsivity in a subset of C-fiber nociceptors in a model of painful diabetic neuropathy in the rat. Neuroscience 2001, 102, 185-192. [CrossRef]

14. Andrew, D.; Greenspan, J.D. Mechanical and Heat Sensitization of Cutaneous Nociceptors after Peripheral Inflammation in the Rat. J. Neurophysiol. 1999, 82, 2649-2656. [CrossRef] [PubMed]

15. Sjöberg, J.; Kanje, M. The initial period of peripheral nerve regeneration and the importance of the local environment for the conditioning lesion effect. Brain Res. 1990, 529, 79-84. [CrossRef]

16. Simone, D.A.; Nolano, M.; Johnson, T.; Wendelschafer-Crabb, G.; Kennedy, W.R. Intradermal injection of capsaicin in humans produces degeneration and subsequent reinnervation of epidermal nerve fibers: Correlation with sensory function. J. Neurosci. 1998, 18, 8947-8959. [CrossRef] [PubMed]

17. Polydefkis, M.; Hauer, P.; Sheth, S.; Sirdofsky, M.; Griffin, J.W.; McArthur, J.C. The time course of epidermal nerve fibre regeneration: Studies in normal controls and in people with diabetes, with and without neuropathy. Brain 2004, 127, 1606-1615. [CrossRef] [PubMed]

18. Hahn, K.; Triolo, A.; Hauer, P.; McArthur, J.C.; Polydefkis, M. Impaired reinnervation in HIV infection following experimental denervation. Neurology 2007, 68, 1251-1256. [CrossRef] [PubMed]

19. Kiryu-Seo, S.; Kiyama, H. Mitochondrial behavior during axon regeneration/degeneration in vivo. Neurosci. Res. 2019, 139, 42-47. [CrossRef] [PubMed]

20. Liu, P.; Peng, J.; Han, G.-H.; Ding, X.; Wei, S.; Gao, G.; Huang, K.; Chang, F.; Wang, Y. Role of macrophages in peripheral nerve injury and repair. Neural Regen. Res. 2019, 14, 1335-1342. [PubMed]

21. Myers, M.I.; Peltier, A.C. Uses of skin biopsy for sensory and autonomic nerve assessment. Curr. Neurol. Neurosci. Rep. 2013, 13, 323. [CrossRef] [PubMed]

22. Lauria, G.; Cornblath, D.R.; Johansson, O.; McArthur, J.C.; Mellgren, S.I.; Nolano, M.; Rosenberg, N.; Sommer, C. European Federation of Neurological Societies EFNS guidelines on the use of skin biopsy in the diagnosis of peripheral neuropathy. Eur. J. Neurol. 2005, 12, 747-758. [CrossRef] [PubMed]

23. Smith, A.G.; Howard, J.R.; Kroll, R.; Ramachandran, P.; Hauer, P.; Singleton, J.R.; McArthur, J. The reliability of skin biopsy with measurement of intraepidermal nerve fiber density. J. Neurol. Sci. 2005, 228, 65-69. [CrossRef] [PubMed]

24. Hlubocky, A.; Wellik, K.; Ross, M.A.; Smith, B.E.; Hoffman-Snyder, C.; Demaerschalk, B.M.; Wingerchuk, D.M. Skin biopsy for diagnosis of small fiber neuropathy: A critically appraised topic. Neurologist 2010, 16, 61-63. [CrossRef] [PubMed]

25. McArthur, J.C.; Stocks, E.A.; Hauer, P.; Cornblath, D.R.; Griffin, J.W. Epidermal nerve fiber density: Normative reference range and diagnostic efficiency. Arch. Neurol. 1998, 55, 1513-1520. [CrossRef] [PubMed]

26. Wu, T.; Ahmed, A.; Bril, V.; Orszag, A.; Ng, E.; Nwe, P.; Perkins, B.A. Variables associated with corneal confocal microscopy parameters in healthy volunteers: Implications for diabetic neuropathy screening. Diabet. Med. 2012, 29, e297-e303. [CrossRef] [PubMed]

27. Tavakoli, M.; Ferdousi, M.; Petropoulos, I.N.; Morris, J.; Pritchard, N.; Zhivov, A.; Ziegler, D.; Pacaud, D.; Romanchuk, K.; Perkins, B.A.; et al. Normative values for corneal nerve morphology assessed using corneal confocal microscopy: A multinational normative data set. Diabetes Care 2015, 38, 838-843. [CrossRef] [PubMed]

28. Ling, L.; Xue, J.; Liu, Y.; Su, L.; Li, H.; Jiang, Y.; Cai, Y.; Zhang, H. Quantitative and morphological study of intraepidermal nerve fibre in healthy individuals. Neurol. Res. 2015, 37, 974-978. [CrossRef] [PubMed]

29. Niederer, R.L.; Perumal, D.; Sherwin, T.; McGhee, C.N.J. Age-related differences in the normal human cornea: A laser scanning in vivo confocal microscopy study. Br. J. Ophthalmol. 2007, 91, 1165-1169. [CrossRef] [PubMed]

30. Lauria, G.; Holland, N.; Hauer, P.; Cornblath, D.R.; Griffin, J.W.; McArthur, J.C. Epidermal innervation: Changes with aging, topographic location, and in sensory neuropathy. J. Neurol. Sci. 1999, 164, 172-178. [CrossRef]

31. Provitera, V.; Gibbons, C.H.; Wendelschafer-Crabb, G.; Donadio, V.; Vitale, D.F.; Stancanelli, A.; Caporaso, G.; Liguori, R.; Wang, N.; Santoro, L.; et al. A multi-center, multinational age- and gender-adjusted normative dataset for immunofluorescent intraepidermal nerve fiber density at the distal leg. Eur. J. Neurol. 2016, 23, 333-338. [CrossRef] [PubMed]

32. Nolano, M.; Simone, D.A.; Wendelschafer-Crabb, G.; Johnson, T.; Hazen, E.; Kennedy, W.R. Topical capsaicin in humans: Parallel loss of epidermal nerve fibers and pain sensation. Pain 1999, 81, 135-145. [CrossRef] 
33. Wehrfritz, A.; Namer, B.; Ihmsen, H.; Mueller, C.; Filitz, J.; Koppert, W.; Leffler, A. Differential effects on sensory functions and measures of epidermal nerve fiber density after application of a lidocaine patch (5\%) on healthy human skin. Eur. J. Pain 2011, 15, 907-912. [CrossRef] [PubMed]

34. Tepelus, T.C.; Chiu, G.B.; Huang, J.; Huang, P.; Sadda, S.R.; Irvine, J.; Lee, O.L. Correlation between corneal innervation and inflammation evaluated with confocal microscopy and symptomatology in patients with dry eye syndromes: A preliminary study. Graefe's Arch. Clin. Exp. Ophthalmol. 2017, 255, 1771-1778. [CrossRef] [PubMed]

35. Theophanous, C.; Jacobs, D.S.; Hamrah, P. Corneal Neuralgia after LASIK. Optom. Vis. Sci. 2015, 92, e233-e240. [CrossRef] [PubMed]

36. Cavalcanti, B.M.; Cruzat, A.; Sahin, A.; Pavan-Langston, D.; Samayoa, E.; Hamrah, P. In vivo confocal microscopy detects bilateral changes of corneal immune cells and nerves in unilateral herpes zoster ophthalmicus. Ocul. Surf. 2018, 16, 101-111. [CrossRef] [PubMed]

37. Kinard, K.I.; Smith, A.G.; Singleton, J.R.; Lessard, M.K.; Katz, B.J.; Warner, J.E.A.; Crum, A.V.; Mifflin, M.D.; Brennan, K.C.; Digre, K.B. Chronic migraine is associated with reduced corneal nerve fiber density and symptoms of dry eye. Headache 2015, 55, 543-549. [CrossRef] [PubMed]

38. Shetty, R.; Deshmukh, R.; Shroff, R.; Dedhiya, C.; Jayadev, C. Subbasal Nerve Plexus Changes in Chronic Migraine. Cornea 2018, 37, 72-75. [CrossRef] [PubMed]

39. Erkan Turan, K.; Kocabeyoglu, S.; Unal-Cevik, I.; Bezci, F.; Akinci, A.; Irkec, M. Ocular Surface Alterations in the Context of Corneal In Vivo Confocal Microscopic Characteristics in Patients with Fibromyalgia. Cornea 2018, 37, 205-210. [CrossRef] [PubMed]

40. Ramírez, M.; Martínez-Martínez, L.-A.; Hernández-Quintela, E.; Velazco-Casapía, J.; Vargas, A.; Martínez-Lavín, M. Small fiber neuropathy in women with fibromyalgia. An in vivo assessment using corneal confocal bio-microscopy. Semin. Arthritis Rheum. 2015, 45, 214-219. [CrossRef] [PubMed]

41. Ferdousi, M.; Azmi, S.; Petropoulos, I.N.; Fadavi, H.; Ponirakis, G.; Marshall, A.; Tavakoli, M.; Malik, I.; Mansoor, W.; Malik, R.A. Corneal Confocal Microscopy Detects Small Fibre Neuropathy in Patients with Upper Gastrointestinal Cancer and Nerve Regeneration in Chemotherapy Induced Peripheral Neuropathy. PLoS ONE 2015, 10, e0139394. [CrossRef] [PubMed]

42. Bucher, F.; Schneider, C.; Blau, T.; Cursiefen, C.; Fink, G.R.; Lehmann, H.C.; Heindl, L.M. Small-Fiber Neuropathy Is Associated with Corneal Nerve and Dendritic Cell Alterations: An In Vivo Confocal Microscopy Study. Cornea 2015, 34, 1114-1119. [CrossRef] [PubMed]

43. Pereira, M.P.; Mühl, S.; Pogatzki-Zahn, E.M.; Agelopoulos, K.; Ständer, S. Intraepidermal Nerve Fiber Density: Diagnostic and Therapeutic Relevance in the Management of Chronic Pruritus: A Review. Derm. Ther. (Heidelb.) 2016, 6, 509-517. [CrossRef] [PubMed]

44. Dhillon, V.K.; Elalfy, M.S.; Al-Aqaba, M.; Gupta, A.; Basu, S.; Dua, H.S. Corneal hypoesthesia with normal sub-basal nerve density following surgery for trigeminal neuralgia. Acta Ophthalmol. 2016, 94, e6-e10. [CrossRef] [PubMed]

45. Bianciardi, G.; Latronico, M.E.; Traversi, C. Entropy of corneal nerve fibers distribution observed by laser scanning confocal microscopy: A noninvasive quantitative method to characterize the corneal innervation in Sjogren's syndrome patients. Microsc. Res. Tech. 2015, 78, 1069-1074. [CrossRef] [PubMed]

46. Gøransson, L.G.; Brun, J.G.; Harboe, E.; Mellgren, S.I.; Omdal, R. Intraepidermal nerve fiber densities in chronic inflammatory autoimmune diseases. Arch. Neurol. 2006, 63, 1410-1413. [CrossRef] [PubMed]

47. Bitirgen, G.; Tinkir Kayitmazbatir, E.; Satirtav, G.; Malik, R.A.; Ozkagnici, A. In Vivo Confocal Microscopic Evaluation of Corneal Nerve Fibers and Dendritic Cells in Patients with Behçet's Disease. Front. Neurol. 2018, 9, 204. [CrossRef] [PubMed]

48. Oudejans, L.C.; Niesters, M.; Brines, M.; Dahan, A.; van Velzen, M. Quantification of small fiber pathology in patients with sarcoidosis and chronic pain using cornea confocal microscopy and skin biopsies. J. Pain Res. 2017, 10, 2057-2065. [CrossRef] [PubMed]

49. Bakkers, M.; Merkies, I.S.J.; Lauria, G.; Devigili, G.; Penza, P.; Lombardi, R.; Hermans, M.C.E.; van Nes, S.I.; De Baets, M.; Faber, C.G. Intraepidermal nerve fiber density and its application in sarcoidosis. Neurology 2009, 73, 1142-1148. [CrossRef] [PubMed]

50. Resch, M.D.; Marsovszky, L.; Németh, J.; Bocskai, M.; Kovács, L.; Balog, A. Dry eye and corneal langerhans cells in systemic lupus erythematosus. J. Ophthalmol. 2015, 2015, 543835. [CrossRef] [PubMed] 
51. Gøransson, L.G.; Tjensvoll, A.B.; Herigstad, A.; Mellgren, S.I.; Omdal, R. Small-diameter nerve fiber neuropathy in systemic lupus erythematosus. Arch. Neurol. 2006, 63, 401-404. [CrossRef] [PubMed]

52. Alam, U.; Jeziorska, M.; Petropoulos, I.N.; Asghar, O.; Fadavi, H.; Ponirakis, G.; Marshall, A.; Tavakoli, M.; Boulton, A.J.M.; Efron, N.; et al. Diagnostic utility of corneal confocal microscopy and intra-epidermal nerve fibre density in diabetic neuropathy. PLoS ONE 2017, 12, e0180175. [CrossRef] [PubMed]

53. Bönhof, G.J.; Strom, A.; Püttgen, S.; Ringel, B.; Brüggemann, J.; Bódis, K.; Müssig, K.; Szendroedi, J.; Roden, M.; Ziegler, D. Patterns of cutaneous nerve fibre loss and regeneration in type 2 diabetes with painful and painless polyneuropathy. Diabetologia 2017, 60, 2495-2503. [CrossRef] [PubMed]

54. Singleton, J.R.; Marcus, R.L.; Lessard, M.K.; Jackson, J.E.; Smith, A.G. Supervised exercise improves cutaneous reinnervation capacity in metabolic syndrome patients. Ann. Neurol. 2015, 77, 146-153. [CrossRef] [PubMed]

55. Sun, B.; Liu, L.-Z.; Li, Y.-F.; Chen, Z.-H.; Ling, L.; Yang, F.; Cui, F.; Huang, X.-S. Clinical Characteristics, Electrophysiology, and Skin Biopsy of 38 Peripheral Neuropathy Cases with Small Fiber Involvement of Various Etiologies. Chin. Med. J. 2017, 130, 1683-1688. [CrossRef] [PubMed]

56. Mimura, T.; Amano, S.; Fukuoka, S.; Honda, N.; Arita, R.; Ochiai, M.; Yanagisawa, M.; Usui, T.; Ono, K.; Araki, F.; et al. In vivo confocal microscopy of hereditary sensory and autonomic neuropathy. Curr. Eye Res. 2008, 33, 940-945. [CrossRef] [PubMed]

57. Shetty, R.; Deshpande, K.; Deshmukh, R.; Jayadev, C.; Shroff, R. Bowman Break and Subbasal Nerve Plexus Changes in a Patient with Dry Eye Presenting With Chronic Ocular Pain and Vitamin D Deficiency. Cornea 2016, 35, 688-691. [CrossRef] [PubMed]

58. Rousseau, A.; Cauquil, C.; Dupas, B.; Labbé, A.; Baudouin, C.; Barreau, E.; Théaudin, M.; Lacroix, C.; Guiochon-Mantel, A.; Benmalek, A.; et al. Potential Role of In Vivo Confocal Microscopy for Imaging Corneal Nerves in Transthyretin Familial Amyloid Polyneuropathy. JAMA Ophthalmol. 2016, 134, 983-989. [CrossRef] [PubMed]

59. Chao, C.-C.; Hsueh, H.-W.; Kan, H.-W.; Liao, C.-H.; Jiang, H.-H.; Chiang, H.; Lin, W.-M.; Yeh, T.-Y.; Lin, Y.-H.; Cheng, Y.-Y.; et al. Skin nerve pathology: Biomarkers of premanifest and manifest amyloid neuropathy. Ann. Neurol. 2019, 85, 560-573. [CrossRef] [PubMed]

60. Schneider, C.; Bucher, F.; Cursiefen, C.; Fink, G.R.; Heindl, L.M.; Lehmann, H.C. Corneal confocal microscopy detects small fiber damage in chronic inflammatory demyelinating polyneuropathy (CIDP). J. Peripher. Nerv. Syst. 2014, 19, 322-327. [CrossRef] [PubMed]

61. Lalive, P.H.; Truffert, A.; Magistris, M.R.; Landis, T.; Dosso, A. Peripheral autoimmune neuropathy assessed using corneal in vivo confocal microscopy. Arch. Neurol. 2009, 66, 403-405. [CrossRef] [PubMed]

62. Kemp, H.I.; Petropoulos, I.N.; Rice, A.S.C.; Vollert, J.; Maier, C.; Strum, D.; Schargus, M.; Peto, T.; Hau, S.; Chopra, R.; et al. Use of Corneal Confocal Microscopy to Evaluate Small Nerve Fibers in Patients with Human Immunodeficiency Virus. JAMA Ophthalmol. 2017, 135, 795-800. [CrossRef] [PubMed]

63. Polydefkis, M.; Yiannoutsos, C.T.; Cohen, B.A.; Hollander, H.; Schifitto, G.; Clifford, D.B.; Simpson, D.M.; Katzenstein, D.; Shriver, S.; Hauer, P.; et al. Reduced intraepidermal nerve fiber density in HIV-associated sensory neuropathy. Neurology 2002, 58, 115-119. [CrossRef] [PubMed]

64. Zhou, L.; Kitch, D.W.; Evans, S.R.; Hauer, P.; Raman, S.; Ebenezer, G.J.; Gerschenson, M.; Marra, C.M.; Valcour, V.; Diaz-Arrastia, R.; et al. Correlates of epidermal nerve fiber densities in HIV-associated distal sensory polyneuropathy. Neurology 2007, 68, 2113-2119. [CrossRef] [PubMed]

65. Gröne, E.; Üçeyler, N.; Abahji, T.; Fleckenstein, J.; Irnich, D.; Mussack, T.; Hoffmann, U.; Sommer, C.; Lang, P.M. Reduced intraepidermal nerve fiber density in patients with chronic ischemic pain in peripheral arterial disease. Pain 2014, 155, 1784-1792. [CrossRef] [PubMed]

66. Tavakoli, M.; Marshall, A.; Banka, S.; Petropoulos, I.N.; Fadavi, H.; Kingston, H.; Malik, R.A. Corneal confocal microscopy detects small-fiber neuropathy in Charcot-Marie-Tooth disease type 1A patients. Muscle Nerve 2012, 46, 698-704. [CrossRef] [PubMed]

67. Duchesne, M.; Danigo, A.; Richard, L.; Vallat, J.-M.; Attarian, S.; Gonnaud, P.-M.; Lacour, A.; Péréon, Y.; Stojkovic, T.; Nave, K.-A.; et al. Skin Biopsy Findings in Patients With CMT1A: Baseline Data From the CLN-PXT3003-01 Study Provide New Insights Into the Pathophysiology of the Disorder. J. Neuropathol. Exp. Neurol. 2018, 77, 274-281. [CrossRef] [PubMed]

68. Kass-Iliyya, L.; Javed, S.; Gosal, D.; Kobylecki, C.; Marshall, A.; Petropoulos, I.N.; Ponirakis, G.; Tavakoli, M.; Ferdousi, M.; Chaudhuri, K.R.; et al. Small fiber neuropathy in Parkinson's disease: A clinical, pathological and corneal confocal microscopy study. Parkinsonism Relat. Disord. 2015, 21, 1454-1460. [CrossRef] [PubMed] 
69. Lin, C.-H.; Chao, C.-C.; Wu, S.-W.; Hsieh, P.-C.; Feng, F.-P.; Lin, Y.-H.; Chen, Y.-M.; Wu, R.-M.; Hsieh, S.-T. Pathophysiology of Small-Fiber Sensory System in Parkinson's Disease: Skin Innervation and Contact Heat Evoked Potential. Medicine (Baltimore) 2016, 95, e3058. [CrossRef] [PubMed]

70. Khan, A.; Kamran, S.; Akhtar, N.; Ponirakis, G.; Al-Muhannadi, H.; Petropoulos, I.N.; Al-Fahdawi, S.; Qahwaji, R.; Sartaj, F.; Babu, B.; et al. Corneal Confocal Microscopy detects a Reduction in Corneal Endothelial Cells and Nerve Fibres in Patients with Acute Ischemic Stroke. Sci. Rep. 2018, 8, 17333. [CrossRef] [PubMed]

71. Tavakoli, M.; Marshall, A.; Thompson, L.; Kenny, M.; Waldek, S.; Efron, N.; Malik, R.A. Corneal confocal microscopy: A novel noninvasive means to diagnose neuropathy in patients with Fabry disease. Muscle Nerve 2009, 40, 976-984. [CrossRef] [PubMed]

72. Üçeyler, N.; He, L.; Schönfeld, D.; Kahn, A.-K.; Reiners, K.; Hilz, M.J.; Breunig, F.; Sommer, C. Small fibers in Fabry disease: Baseline and follow-up data under enzyme replacement therapy. J. Peripher. Nerv. Syst. 2011, 16, 304-314. [CrossRef] [PubMed]

73. Dalla Bella, E.; Lombardi, R.; Porretta-Serapiglia, C.; Ciano, C.; Gellera, C.; Pensato, V.; Cazzato, D.; Lauria, G. Amyotrophic lateral sclerosis causes small fiber pathology. Eur. J. Neurol. 2016, 23, 416-420. [CrossRef] [PubMed]

74. Mikolajczak, J.; Zimmermann, H.; Kheirkhah, A.; Kadas, E.M.; Oberwahrenbrock, T.; Muller, R.; Ren, A.; Kuchling, J.; Dietze, H.; Prüss, H.; et al. Patients with multiple sclerosis demonstrate reduced subbasal corneal nerve fibre density. Mult. Scler. 2017, 23, 1847-1853. [CrossRef] [PubMed]

75. Sturniolo, G.C.; Lazzarini, D.; Bartolo, O.; Berton, M.; Leonardi, A.; Fregona, I.A.; Parrozzani, R.; Midena, E. Small fiber peripheral neuropathy in Wilson disease: An in vivo documentation by corneal confocal microscopy. Investig. Ophthalmol. Vis. Sci. 2015, 56, 1390-1395. [CrossRef] [PubMed]

76. Pagovich, O.E.; Vo, M.L.; Zhao, Z.Z.; Petropoulos, I.N.; Yuan, M.; Lertsuwanroj, B.; Ciralsky, J.; Lai, E.; Kiss, S.; D'Amico, D.J.; et al. Corneal confocal microscopy: Neurologic disease biomarker in Friedreich ataxia. Ann. Neurol. 2018, 84, 893-904. [CrossRef] [PubMed]

77. Indelicato, E.; Nachbauer, W.; Eigentler, A.; Rudzki, D.; Wanschitz, J.; Boesch, S. Intraepidermal Nerve Fiber Density in Friedreich's Ataxia. J. Neuropathol. Exp. Neurol. 2018, 77, 1137-1143. [CrossRef] [PubMed]

78. Villani, E.; Garoli, E.; Bassotti, A.; Magnani, F.; Tresoldi, L.; Nucci, P.; Ratiglia, R. The cornea in classic type Ehlers-Danlos syndrome: Macro- and microstructural changes. Investig. Ophthalmol. Vis. Sci. 2013, 54, 8062-8068. [CrossRef] [PubMed]

79. Cazzato, D.; Castori, M.; Lombardi, R.; Caravello, F.; Bella, E.D.; Petrucci, A.; Grammatico, P.; Dordoni, C.; Colombi, M.; Lauria, G. Small fiber neuropathy is a common feature of Ehlers-Danlos syndromes. Neurology 2016, 87, 155-159. [CrossRef] [PubMed]

80. González-Duarte, A.; Lem, M.; Díaz-Díaz, E.; Castillo, C.; Cárdenas-Soto, K. The Efficacy of Pregabalin in the Treatment of Prediabetic Neuropathic Pain. Clin. J. Pain 2016, 32, 927-932. [CrossRef] [PubMed]

81. Villani, E.; Garoli, E.; Termine, V.; Pichi, F.; Ratiglia, R.; Nucci, P. Corneal Confocal Microscopy in Dry Eye Treated with Corticosteroids. Optom. Vis. Sci. 2015, 92, e290-e295. [CrossRef] [PubMed]

82. Iaccheri, B.; Torroni, G.; Cagini, C.; Fiore, T.; Cerquaglia, A.; Lupidi, M.; Cillino, S.; Dua, H.S. Corneal confocal scanning laser microscopy in patients with dry eye disease treated with topical cyclosporine. Eye (Lond.) 2017, 31, 788-794. [CrossRef] [PubMed]

83. Culver, D.A.; Dahan, A.; Bajorunas, D.; Jeziorska, M.; van Velzen, M.; Aarts, L.P.H.J.; Tavee, J.; Tannemaat, M.R.; Dunne, A.N.; Kirk, R.I.; et al. Cibinetide Improves Corneal Nerve Fiber Abundance in Patients with Sarcoidosis-Associated Small Nerve Fiber Loss and Neuropathic Pain. Investig. Ophthalmol. Vis. Sci. 2017, 58, BIO52-BIO60. [CrossRef] [PubMed]

84. Stuard, W.L.; Gallerson, B.K.; Robertson, D.M. Alterations in corneal nerves following crack cocaine use mimic diabetes-induced nerve damage. Endocrinol. Diabetes Metab. Case Rep. 2017, 2017, 16-131. [CrossRef] [PubMed]

85. Güneş, H.N.; Bekircan-Kurt, C.E.; Tan, E.; Erdem-Özdamar, S. The histopathological evaluation of small fiber neuropathy in patients with vitamin B12 deficiency. Acta Neurol. Belg. 2018, 118, 405-410. [CrossRef] [PubMed]

86. Jin, P.; Cheng, L.; Chen, M.; Zhou, L. Low Sensitivity of Skin Biopsy in Diagnosing Small Fiber Neuropathy in Chinese Americans. J. Clin. Neuromuscul. Dis. 2018, 20, 1-6. [CrossRef] [PubMed]

87. Besné, I.; Descombes, C.; Breton, L. Effect of age and anatomical site on density of sensory innervation in human epidermis. Arch. Dermatol. 2002, 138, 1445-1450. [CrossRef] [PubMed] 
88. Kissel, J.T.; Smith, A.G. Understanding Small Fiber Neuropathy: The Long and Short of It. JAMA Neurol. 2016, 73, 635-637. [CrossRef] [PubMed]

89. Podgorny, P.J.; Suchowersky, O.; Romanchuk, K.G.; Feasby, T.E. Evidence for small fiber neuropathy in early Parkinson's disease. Parkinsonism Relat. Disord. 2016, 28, 94-99. [CrossRef] [PubMed]

90. Nolano, M.; Provitera, V.; Manganelli, F.; Iodice, R.; Caporaso, G.; Stancanelli, A.; Marinou, K.; Lanzillo, B.; Santoro, L.; Mora, G. Non-motor involvement in amyotrophic lateral sclerosis: New insight from nerve and vessel analysis in skin biopsy. Neuropathol. Appl. Neurobiol. 2017, 43, 119-132. [CrossRef] [PubMed]

91. Ren, Y.; Liu, W.; Li, Y.; Sun, B.; Li, Y.; Yang, F.; Wang, H.; Li, M.; Cui, F.; Huang, X. Cutaneous somatic and autonomic nerve TDP-43 deposition in amyotrophic lateral sclerosis. J. Neurol. 2018, 265, 1753-1763. [CrossRef] [PubMed]

92. Malik, R.A.; Kallinikos, P.; Abbott, C.A.; van Schie, C.H.M.; Morgan, P.; Efron, N.; Boulton, A.J.M. Corneal confocal microscopy: A non-invasive surrogate of nerve fibre damage and repair in diabetic patients. Diabetologia 2003, 46, 683-688. [CrossRef] [PubMed]

93. Dehghani, C.; Pritchard, N.; Edwards, K.; Russell, A.W.; Malik, R.A.; Efron, N. Fully automated, semiautomated, and manual morphometric analysis of corneal subbasal nerve plexus in individuals with and without diabetes. Cornea 2014, 33, 696-702. [CrossRef] [PubMed]

94. Kalteniece, A.; Ferdousi, M.; Adam, S.; Schofield, J.; Azmi, S.; Petropoulos, I.; Soran, H.; Malik, R.A. Corneal confocal microscopy is a rapid reproducible ophthalmic technique for quantifying corneal nerve abnormalities. PLoS ONE 2017, 12, e0183040. [CrossRef] [PubMed]

95. Petropoulos, I.N.; Alam, U.; Fadavi, H.; Marshall, A.; Asghar, O.; Dabbah, M.A.; Chen, X.; Graham, J.; Ponirakis, G.; Boulton, A.J.M.; et al. Rapid automated diagnosis of diabetic peripheral neuropathy with in vivo corneal confocal microscopy. Investig. Ophthalmol. Vis. Sci. 2014, 55, 2071-2078. [CrossRef] [PubMed]

96. Kheirkhah, A.; Muller, R.; Mikolajczak, J.; Ren, A.; Kadas, E.M.; Zimmermann, H.; Pruess, H.; Paul, F.; Brandt, A.U.; Hamrah, P. Comparison of Standard Versus Wide-Field Composite Images of the Corneal Subbasal Layer by In Vivo Confocal Microscopy. Investig. Ophthalmol. Vis. Sci. 2015, 56, 5801-5807. [CrossRef] [PubMed]

97. Allgeier, S.; Bartschat, A.; Bohn, S.; Peschel, S.; Reichert, K.-M.; Sperlich, K.; Walckling, M.; Hagenmeyer, V.; Mikut, R.; Stachs, O.; et al. 3D confocal laser-scanning microscopy for large-area imaging of the corneal subbasal nerve plexus. Sci. Rep. 2018, 8, 7468. [CrossRef] [PubMed]

98. Chen, X.; Graham, J.; Dabbah, M.A.; Petropoulos, I.N.; Tavakoli, M.; Malik, R.A. An Automatic Tool for Quantification of Nerve Fibers in Corneal Confocal Microscopy Images. IEEE Trans. Biomed. Eng. 2017, 64, 786-794. [CrossRef] [PubMed]

99. Chen, X.; Graham, J.; Dabbah, M.A.; Petropoulos, I.N.; Ponirakis, G.; Asghar, O.; Alam, U.; Marshall, A.; Fadavi, H.; Ferdousi, M.; et al. Small nerve fiber quantification in the diagnosis of diabetic sensorimotor polyneuropathy: Comparing corneal confocal microscopy with intraepidermal nerve fiber density. Diabetes Care 2015, 38, 1138-1144. [CrossRef] [PubMed]

100. Hertz, P.; Bril, V.; Orszag, A.; Ahmed, A.; Ng, E.; Nwe, P.; Ngo, M.; Perkins, B.A. Reproducibility of in vivo corneal confocal microscopy as a novel screening test for early diabetic sensorimotor polyneuropathy. Diabet. Med. 2011, 28, 1253-1260. [CrossRef] [PubMed]

101. Brines, M.; Culver, D.A.; Ferdousi, M.; Tannemaat, M.R.; van Velzen, M.; Dahan, A.; Malik, R.A. Corneal nerve fiber size adds utility to the diagnosis and assessment of therapeutic response in patients with small fiber neuropathy. Sci. Rep. 2018, 8, 4734. [CrossRef] [PubMed]

102. Mehra, S.; Tavakoli, M.; Kallinikos, P.A.; Efron, N.; Boulton, A.J.M.; Augustine, T.; Malik, R.A. Corneal confocal microscopy detects early nerve regeneration after pancreas transplantation in patients with type 1 diabetes. Diabetes Care 2007, 30, 2608-2612. [CrossRef] [PubMed]

103. Petropoulos, I.N.; Kamran, S.; Li, Y.; Khan, A.; Ponirakis, G.; Akhtar, N.; Deleu, D.; Shuaib, A.; Malik, R.A. Corneal Confocal Microscopy: An Imaging Endpoint for Axonal Degeneration in Multiple Sclerosis. Investig. Ophthalmol. Vis. Sci. 2017, 58, 3677-3681. [CrossRef] [PubMed]

104. Stettner, M.; Hinrichs, L.; Guthoff, R.; Bairov, S.; Petropoulos, I.N.; Warnke, C.; Hartung, H.-P.; Malik, R.A.; Kieseier, B.C. Corneal confocal microscopy in chronic inflammatory demyelinating polyneuropathy. Ann. Clin. Transl. Neurol. 2016, 3, 88-100. [CrossRef] [PubMed] 
105. Pritchard, N.; Edwards, K.; Russell, A.W.; Perkins, B.A.; Malik, R.A.; Efron, N. Corneal confocal microscopy predicts 4-year incident peripheral neuropathy in type 1 diabetes. Diabetes Care 2015, 38, 671-675. [CrossRef] [PubMed]

106. Kalteniece, A.; Ferdousi, M.; Petropoulos, I.; Azmi, S.; Adam, S.; Fadavi, H.; Marshall, A.; Boulton, A.J.M.; Efron, N.; Faber, C.G.; et al. Greater corneal nerve loss at the inferior whorl is related to the presence of diabetic neuropathy and painful diabetic neuropathy. Sci. Rep. 2018, 8, 3283. [CrossRef] [PubMed]

107. Chen, D. Safety Evaluation of Light Levels in Ophthalmic Instruments and Devices. Master's Thesis, University of Houston, Houston, TX, USA, May 2016.

108. Nandakumar, G. Skin biopsy in pediatric age group: Special considerations. Indian J. Paediatr. Dermatol. 2012, 13, 35. [CrossRef]

109. Nolano, M.; Provitera, V.; Manganelli, F.; Iodice, R.; Stancanelli, A.; Caporaso, G.; Saltalamacchia, A.; Califano, F.; Lanzillo, B.; Picillo, M.; et al. Loss of cutaneous large and small fibers in naive and l-dopa-treated PD patients. Neurology 2017, 89, 776-784. [CrossRef] [PubMed]

110. Ponirakis, G.; Al Hamad, H.; Sankaranarayanan, A.; Khan, A.; Chandran, M.; Ramadan, M.; Tosino, R.; Gawhale, P.V.; Alobaidi, M.; AlSulaiti, E.; et al. Association of corneal nerve fiber measures with cognitive function in dementia. Ann. Clin. Transl. Neurol. 2019, 6, 689-697. [CrossRef] [PubMed]

111. Erie, J.C.; McLaren, J.W.; Hodge, D.O.; Bourne, W.M. Recovery of corneal subbasal nerve density after PRK and LASIK. Am. J. Ophthalmol. 2005, 140, 1059-1064. [CrossRef] [PubMed]

112. Bandeira, F.; Yusoff, N.Z.; Yam, G.H.-F.; Mehta, J.S. Corneal re-innervation following refractive surgery treatments. Neural Regen. Res. 2019, 14, 557-565. [PubMed]

113. Müller, R.T.; Abedi, F.; Cruzat, A.; Witkin, D.; Baniasadi, N.; Cavalcanti, B.M.; Jamali, A.; Chodosh, J.; Dana, R.; Pavan-Langston, D.; et al. Degeneration and Regeneration of Subbasal Corneal Nerves after Infectious Keratitis: A Longitudinal In Vivo Confocal Microscopy Study. Ophthalmology 2015, 122, 2200-2209. [CrossRef] [PubMed]

114. Al Rashah, K.; Pritchard, N.; Dehghani, C.; Ruggeri, A.; Guimaraes, P.; Russell, A.; Malik, R.A.; Efron, N.; Edwards, K. Corneal Nerve Migration Rate in a Healthy Control Population. Optom. Vis. Sci. 2018, 95, 672-677. [CrossRef] [PubMed]

115. Di, G.; Qi, X.; Zhao, X.; Zhang, S.; Danielson, P.; Zhou, Q. Corneal Epithelium-Derived Neurotrophic Factors Promote Nerve Regeneration. Investig. Ophthalmol. Vis. Sci. 2017, 58, 4695-4702. [CrossRef] [PubMed]

116. He, J.; Pham, T.L.; Kakazu, A.; Bazan, H.E.P. Recovery of Corneal Sensitivity and Increase in Nerve Density and Wound Healing in Diabetic Mice After PEDF Plus DHA Treatment. Diabetes 2017, 66, 2511-2520. [CrossRef] [PubMed]

117. Wang, Y.; Zhao, X.; Wu, X.; Dai, Y.; Chen, P.; Xie, L. microRNA-182 Mediates Sirt1-Induced Diabetic Corneal Nerve Regeneration. Diabetes 2016, 65, 2020-2031. [CrossRef] [PubMed]

118. Pan, Y.; Liu, F.; Qi, X.; Hu, Y.; Xu, F.; Jia, H. Nerve Growth Factor Changes and Corneal Nerve Repair after Keratoplasty. Optom. Vis. Sci. 2018, 95, 27-31. [CrossRef] [PubMed]

119. Campero, M.; Baumann, T.K.; Bostock, H.; Ochoa, J.L. Human cutaneous C fibres activated by cooling, heating and menthol. J. Physiol. (Lond.) 2009, 587, 5633-5652. [CrossRef] [PubMed]

120. Krishnan, S.T.M.; Rayman, G. The LDIflare: A novel test of C-fiber function demonstrates early neuropathy in type 2 diabetes. Diabetes Care 2004, 27, 2930-2935. [CrossRef] [PubMed]

121. Rodrigues Júnior, I.A.; Silva, I.C.C.; Gresta, L.T.; Lyon, S.; Villarroel, M.d.F.; Arantes, R.M.E. Degree of skin denervation and its correlation to objective thermal sensory test in leprosy patients. PLoS Negl. Trop. Dis. 2012, 6, e1975. [CrossRef] [PubMed]

122. Kovács, I.; Luna, C.; Quirce, S.; Mizerska, K.; Callejo, G.; Riestra, A.; Fernández-Sánchez, L.; Meseguer, V.M.; Cuenca, N.; Merayo-Lloves, J.; et al. Abnormal activity of corneal cold thermoreceptors underlies the unpleasant sensations in dry eye disease. Pain 2016, 157, 399-417. [CrossRef] [PubMed]

123. Kurose, M.; Meng, I.D. Dry eye modifies the thermal and menthol responses in rat corneal primary afferent cool cells. J. Neurophysiol. 2013, 110, 495-504. [CrossRef] [PubMed]

124. Tanelian, D.L.; Monroe, S. Altered thermal responsiveness during regeneration of corneal cold fibers. J. Neurophysiol. 1995, 73, 1568-1573. [CrossRef] [PubMed]

125. Wöpking, S.; Scherens, A.; Haussleiter, I.S.; Richter, H.; Schüning, J.; Klauenberg, S.; Maier, C. Significant difference between three observers in the assessment of intraepidermal nerve fiber density in skin biopsy. BMC Neurol. 2009, 9, 13. [CrossRef] [PubMed] 
126. Al-Fahdawi, S.; Qahwaji, R.; Al-Waisy, A.S.; Ipson, S.; Malik, R.A.; Brahma, A.; Chen, X. A fully automatic nerve segmentation and morphometric parameter quantification system for early diagnosis of diabetic neuropathy in corneal images. Comput. Methods Programs Biomed. 2016, 135, 151-166. [CrossRef] [PubMed]

127. Ferreira, A.; Morgado, A.M.; Silva, J.S. A method for corneal nerves automatic segmentation and morphometric analysis. Comput. Methods Programs Biomed. 2012, 107, 53-60. [CrossRef] [PubMed]

128. Lovblom, L.E.; Halpern, E.M.; Wu, T.; Kelly, D.; Ahmed, A.; Boulet, G.; Orszag, A.; Ng, E.; Ngo, M.; Bril, V.; et al. In vivo corneal confocal microscopy and prediction of future-incident neuropathy in type 1 diabetes: A preliminary longitudinal analysis. Can. J. Diabetes 2015, 39, 390-397. [CrossRef] [PubMed]

129. Ahmed, A.; Bril, V.; Orszag, A.; Paulson, J.; Yeung, E.; Ngo, M.; Orlov, S.; Perkins, B.A. Detection of diabetic sensorimotor polyneuropathy by corneal confocal microscopy in type 1 diabetes: A concurrent validity study. Diabetes Care 2012, 35, 821-828. [CrossRef] [PubMed]

130. Ambrósio, R.; Tervo, T.; Wilson, S.E. LASIK-associated dry eye and neurotrophic epitheliopathy: Pathophysiology and strategies for prevention and treatment. J. Refract. Surg. 2008, 24, 396-407. [CrossRef] [PubMed]

131. Patel, D.V.; McGhee, C.N.J. In vivo confocal microscopy of human corneal nerves in health, in ocular and systemic disease, and following corneal surgery: A review. Br. J. Ophthalmol. 2009, 93, 853-860. [CrossRef] [PubMed]

132. Hsieh, C.-H.; Jeng, S.-F.; Lu, T.-H.; Chen, Y.-C.; Hsieh, M.-W.; Chen, S.-S. Loss of small fibers in entrapment neuropathy and their regeneration after surgical decompression in a rat model. J. Neurotrauma 2007, 24, 1658-1666. [CrossRef] [PubMed]

(C) 2019 by the authors. Licensee MDPI, Basel, Switzerland. This article is an open access article distributed under the terms and conditions of the Creative Commons Attribution (CC BY) license (http://creativecommons.org/licenses/by/4.0/). 